\title{
Partial Survey of Date Palm Dust Mite, Oligonychus afrasiaticus (McGregor) in Egypt Including Historical Trait
}

\author{
A. S. Sanad; A. S. Elhalawany; \\ M. M. Abou-Setta and Hanaa M. El-khateeb \\ Fruit Trees Mites Dept., Plant Protec. Res. Inst., ARC, Dokii, Giza, Egypt.
}

\begin{abstract}
The economic importance of date palm tree Phoenix, dactylifera L. exceeds its nutrition value as the most valuable fruit. Preserve Egypt's international status as a large producer of dates in the world, requires tackling pests that attack palm trees. Diseases and pathogen pests are causing great economic loss to the growers, reducing about $52 \%$ of the total yield. Oligonychus afrasiaticus (McGregor) (Acari: Tetranychidae) is a dominant acarine pest in date palm production area in the Middle East and North Africa. Current survey covered different date palm plantation in Giza, Assiut, Matruh and the New Valley Governorates. Results showed that the dust mite has spread out to promising agricultural expansion areas. This finding sets the alarm of existing this mite as a new potential pest for date palm industry in the New Valley governorate. It is a more important problem for new introduced varieties as the high cash crop Barhi variety (soft variety). The existence of this species in Egypt was firstly mentioned in 1979 at Al-Kharga oasis, the New Valley. A historical trait of this mite pest over Egypt was included.
\end{abstract}

Key words: Date palm, Dust mite, Oligonychus afrasiaticus.

\section{INTRODUCTION}

The date palm tree, Phoenix dactylifera L., has great socioeconomic, environmental importance and nutritional value in Egypt. Its traditional use as a primary source of food and by-products and its ecological benefits in oasis agriculture make it an important fruit tree and the best crop to be cultivated.

About 55 cultivars of date palm fruits are commercially produced in Egypt (Bekheet and El-Sharabasy, 2015). These cultivars are classified as soft, semi dry and dry ones. They also indicated that more than one hundred industries relying on date palm products.

Egypt is a productive country of date palm fruits. It produces an amount of $1,470,000$ metric tons, contributing $17 \%$ of world production (FAO STAT, 2012).

Diseases and pests are serious threat to date palm plantations, causing great economic loss to the growers in Egypt. They reduce about $52 \%$ of the total yield (Central Administration for Agricultural Extension Services, Egypt, 2001).

Date palm trees are attacked by several mite species that frequently cause significant damage. The Banks grass mite, Oligonychus pratensis (Banks), and the Old World date mite, Oligonychus afrasiaticus (McGregor), (Acari: Tetranychidae) is considered as major pests of date palms (Negm et al., 2015).

This work aimed to review the previous scientific efforts in this field in Egypt. Also, presents survey results of the geographical distribution of this serious mite pest in Giza, Assiut, Matruh and the New Valley Governorates, with special reference to new cultivated areas in the New Valley (Ewinat) and suggesting further search points to be approached.

\section{MATERIALS AND METHODS}

A survey was conducted during May - July 2016 and 2017 in Giza, Assiut, Matruh and the New Valley governorates. Survey covered different common date palm dominant varieties plantation in different localities of the four visited governorates. Samples of date palm leaves and dates were collected. Inspection focused on the dust mite infestation symptoms. Heavily silk webbing on bunches was a primer sign on the occurrence of the dust mites. Samples were transferred to the laboratory for examination using a binocular microscope.

Specimens were identified according to Jeppson et al. (1975) and Zaher et al. (1982). Two groups of specimens $\left(2\right.$ \& \& $\left.2{ }^{\Uparrow}\right)$ of the collected species were deposited in the Reference Collection of the Department of Zoology and Nematology, Faculty of Agricultural, Cairo University and the Reference Collection of Acarology at Fruit Trees Department, Plant Protection Research Institute, Egypt.

\section{RESULTS AND DISCUSSION}

The field observations revealed that date palm dust mite $O$. afrasiaticus spread out in new localities of the Egyptian cultivation area. Surveying results of dust mite, associated with the date palms in Giza, Assiut, Matruh and the New Valley Governorates are presented in Table (1). 
Table (1): Occurrence of dust mite, Oligonychus afrasiaticus on date palm plants at Giza, Assiut, Matruh and New Valley, Egypt during 2016-2017.

\begin{tabular}{|c|c|c|c|c|c|c|c|}
\hline \multirow[b]{2}{*}{ Locality } & \multicolumn{6}{|c|}{ Date palm variety } & \multirow[b]{2}{*}{ Governorate } \\
\hline & $\begin{array}{l}\text { Barhi } \\
\text { (soft) }\end{array}$ & $\begin{array}{l}\text { Zaghloul } \\
\text { (soft) }\end{array}$ & $\begin{array}{l}\text { Samani } \\
\text { (soft) }\end{array}$ & $\begin{array}{c}\text { Siwy } \\
\text { (semidry) }\end{array}$ & $\begin{array}{c}\text { Sakkoty, } \\
\text { Bartamoda and } \\
\text { Shamiya (dry) }\end{array}$ & $\begin{array}{l}\text { Date palms of } \\
\text { seed origin }\end{array}$ & \\
\hline $\begin{array}{l}\text { Giza } \\
\text { (Giza City) }\end{array}$ & - & - & - & - & - & $\begin{array}{c}O . \\
\text { afrasiaticus }\end{array}$ & Giza \\
\hline $\begin{array}{l}\text { Bahariya Oasis } \\
\text { (Elheez Village) }\end{array}$ & - & - & - & $\begin{array}{c}O . \\
\text { afrasiaticus }\end{array}$ & - & - & Giza \\
\hline $\begin{array}{l}\text { New Assiut city } \\
\text { (Assiut Vally) }\end{array}$ & - & $\begin{array}{c}O . \\
\text { afrasiaticus }\end{array}$ & $\begin{array}{c}O . \\
\text { afrasiaticus }\end{array}$ & - & - & - & Assiut \\
\hline $\begin{array}{l}\text { Dakhla Oasis } \\
\text { (Assment Village) }\end{array}$ & - & - & - & $\begin{array}{c}O . \\
\text { afrasiaticus }\end{array}$ & - & - & New Valley \\
\hline $\begin{array}{l}\text { Kharga Oasis } \\
\text { (Nasser Village) }\end{array}$ & - & - & - & $\begin{array}{c}O . \\
\text { afrasiaticus }\end{array}$ & - & - & New Valley \\
\hline $\begin{array}{l}\text { Paries Oasis } \\
\text { (El-Moks Village) }\end{array}$ & - & - & - & $\begin{array}{c}O . \\
\text { afrasiaticus }\end{array}$ & - & $\begin{array}{c}O . \\
\text { afrasiaticus }\end{array}$ & New Valley \\
\hline $\begin{array}{l}\text { Ewinat reclamed land } \\
\text { (El-Ain Village) }\end{array}$ & $\begin{array}{c}O . \\
\text { afrasiaticus }\end{array}$ & - & - & - & $\begin{array}{c}O . \\
\text { afrasiaticus }\end{array}$ & $\begin{array}{c}O . \\
\text { afrasiaticus }\end{array}$ & New Valley \\
\hline $\begin{array}{l}\text { Siwa Oasis } \\
\text { (Siwa City) }\end{array}$ & - & - & - & $\begin{array}{c}O . \\
\text { afrasiaticus }\end{array}$ & - & - & Matruh \\
\hline
\end{tabular}

\section{Documented history of dust mite in Egypt:}

The first report of Oligonychus spp. as date palm common pests was in Kharga Oasis on Sewy semi dry variety (Saleh and Hosny, 1979). They indicated that the infestation rate could reach $100 \%$ of the infested bunches. However, the first record of Oligonychus afrasiaticus (McGregor) and O. pratensis (Banks) was reported on the weed, Cynodon dactylon Pers., in El-Ismailia and in Giza (Zaher et al., 1982).

O. afrasiaticus was documented during survey of mites associated with palm trees in North and South Sinai Peninsula (El-Kady, 1997).

$O$. afrasiaticus was recorded on date palms with high population as a serious pest allover Egypt (ElHalawany et al., 2001). These results was confirmed in ecological studies conducted on phytophagous mites inhabiting date palm plants at several governorates in Lower Egypt with special interest in O. afrasiaticus biology and its control (Rawash, 2003 unpublished M. Sc. Thesis).

Oligonychus sp. was found during the survey of different mites associated with date palm at Rashid region, El Beheira Governorate, Egypt. (Sallam et al., 2007).

O. afrsiaticus was reported from Giza and Sohag Governorates as mite species associated with two varieties of date palm, including their abundance on Zaghloul and Sewy soft and semi dry varieties (ElSanady and Mohamed, 2013). This species was also reported as one of three mite species occurring on date palms at the New Valley (Negm, 2015).

$O$. pratensis population fluctuations study was conducted on infested Zea mays L. at El-Sharkia and El-Dakahlia Governorates (Omar et al., 2013).
It is worth mentioning that $O$. afrasiaticus is a dominant acarin pest in date palm production area in the Middle East (including Saudi Arabia, Oman, UAE, Iraq and Palestine). It also occurs in North Africa including Egypt (Negm et al., 2015).

The present study recorded the date palm dust mite, $O$. afrasiaticus as a serious pest in new localities and new varieties which haven't been recorded before in Egypt. This finding sets the alarm of existence of this mite as new potential pest for date palm industry in the New Valley Governorate. It is more important problem for new introduced varieties as the high cash crop Barhi (soft variety).

The occurrence of $O$. afrasiaticus at other soft varieties like Zaghloul and Samani had grabed the attention in Assiut Governorate, and the existence of this mite on Siwy variety (semidry) at Siwa also is a new findings at present work.

It is important to scout periodically and to survey pest species of such economic importance to date palm trees and even on wild plants to update the knowledge of the animal faunae. This would help in predicting its peaks to prevent any unexpected damage.

The lake of local studies related to different varieties susceptibility to dust palm mite infestation and its biological traits, geographical distribution in all Egyptian date palm planting areas and/or varieties can mislead the control of this serious pest and threaten the expansion of the production area of date palm to fulfill local consumption in the whole country and to produce date fruits for export purposes.

The different control strategies proposed in (Negm et al., 2015) indicated that the hope in controlling this 
serious pest depends only on the integrated work (i.e. host plant resistance, agriculture, chemical and biological control practices).

More efforts is required in this prospective for continues monitoring, status evaluation and control strategy to contain the expansion of this mite as main pest of date palm trees in the survived areas as well as other date palm production areas in Egypt.

\section{ACKNOWLEDGMENTS}

The efforts and facilities to conduct this survey provided by Eng. Ashraf Abd El-Razik and Eng. Ibrahim Sorour, Secretaries of Agriculture Affaire are appreciated. Without this help the conducted work would not be existed.

\section{REFERENCES}

Bekheet S.A. and El-Sharabasy, S.F. 2015. Date palm status and perspective in Egypt. In: Date Palm Genetic Resources and Utilization, Vol. 1: Africa and the Americas edited by Al-Khayri, Shri Mohan and Jain Dennis V. Johnson 545 pp Springer, Dordrecht, Heidelberg New York, London.

Central Administration for Agricultural Extension, Egypt. 2001. Date palm. Bulletin No. 710, 2001, Ministry of Agriculture and Land Reclamation (in Arabic). Cairo, Egypt.

El-Halawany, M. E.; Abdel-Samad, M. A. and El-Naggar, M. E. 2001. Mites inhabiting date palms. Proc. Second International Conference on Date Palms, March 25-27, 2001, Al-Ain, UAE, pp. 366-373.

El-Kady, G.A. 1997. Mites associated with date palm trees in North and South Sinai Peninsula. $7^{\text {th }}$ Nat. Conf. of Pest. and Dis. of Vegetables and Fruits in Egypt, pp.789-806.

El-Sanady, M. A. and Mohamed, A. A. 2013. Biodiversity and seasonal abundance of mites associated with two varieties of date palm in Giza and Sohag Governorates, Egypt. ACARINES, 7: 57-62.

FAO STAT. 2012. Food and Agricultural Organization Corporate Statistical Database. FAO, Rome.

Jeppson, L. R.; Keifer, H. H. and Baker, E. W. 1975. Mites injurious to economic plants. Berkeley: University of California Press, $614 \mathrm{pp}$.

Negm, M.W. 2015. Biological control of phytophagous mites in the New Valley. Ecological Newsletter, Faculty of Agriculture, Assiut Univ., 12: 1-2.

Negm, M.W.; De Moraes, G. J. and Perring, T. M. 2015. Mite pests of date palms. In: Wakil et al., (eds.), Sustainable pest management in date palm: Current status and emerging challenges, sustainability in plant and crop protection, pp 347 - 390. Springer International Publishing Switzerland.

Omar, N. A.; Mohamed, O. M. O. and El-Sanady, M. A. 2013. Population fluctuations of Oligonychus pratensis (Banks) and its predator Amblyseius zaheri Yousef \& El-Brollosy in Egypt (Tetranychidae, Phytoseiidae). Res. J Agric. Biol. Sci., 9:89-95.

Rawash, A. F. 2003. Ecological and biological studies on some mites which infested date palm and their control. M.Sc. Thesis Fac. Agic. Zagazig Univ. (Moshtohor Branch), 99 pp.

Saleh, M. R. A. and Hosny, M. M. 1979. Observation on Oligonychus spp. occurring on date bunches (Acari: Tetranychidae). Ain Shams Univ. Res. Bull., 1014: 1-8.

Sallam G. M.; Yassin E. M. and Abd EL-Azeim N. A. 2007. The predatory insects, mites and spiders associated with date palm pests in Rashid Region, El-Beheira Governorate, Egypt. J. Agric. Res., 85: 37- 51.

Zaher, M. A.; Gomaa, E. A., and El-Enany, M. A. 1982. Spider mites of Egypt (Acari: Tetranychidae). Intern. J. Acarol., 8: 91-114. 